\title{
Library Book Sharing Network (LBSN)
}

\author{
Syed Asif Ali, PhD \\ Sindh Madressatul Islam \\ University \\ Karachi, Pakistan
}

\author{
Basit Hassan Qureshi \\ Sindh Madressatul Islam \\ University \\ Karachi, Pakistan
}

\author{
Syeda Wajiha Naim \\ Sindh Madressatul Islam \\ University \\ Karachi, Pakistan
}

\author{
Maham Nasrullah \\ Sindh Madressatul Islam \\ University \\ Karachi, Pakistan
}

\begin{abstract}
This paper consists of all related information of the Library Book Share Network, from perspective of students and librarians. It then explores some of the problems and issues faced by students, if they are unable to find their desired book in their campus library. The paper stresses the need of how Library Network is important and how it will benefit students and will decrease work load of librarians. The paper emphasizes on sharing books among each other within the network.
\end{abstract}

\section{Keywords}

Library, borrow books, travelling salesmen algorithm, network, E-Books.

\section{INTRODUCTION}

Library network is a web-based application network, in which a group of libraries will be registered and will share their collection of books with their nearest libraries. In this way if any book is not available in a library; they can generate their request and the ones who are having those books will accept the request and approach them. An individual will not be able to access the books directly, they can borrow or give any book, via being a member of any one of the libraries. To avail the services of this Library Network, first you must be member of any one library. For example, if an individual is the member of SMIU Library and SMIU Library is registered on this network he or she will easily borrow book. Books will be borrowed on some terms and conditions, which includes the duration and in case if any book is damaged the person who borrowed the book will have to pay for it.

Library Network is expanded up-to 3 levels, region to city, city to area, area to various library cells. Give and take of books will be based on some terms and conditions, discussed in proposed system of this paper.

\section{LITERATURE REVIEW}

HEC Digital Library is an online platform in which, researchers can be facilitated by international scholarly literature, with online delivery. Books related to variety of subject areas are available, providing access to high quality, peer-reviewed journals, databases articles and e-books. Content of about 75000 books has been made available through which researchers can be benefited. This e-book supported program provides researchers with online books, which can help them to get valuable information for any topic they are studying. This program provides books only in softcopy, these books include various reference books as well [3].

Open Textbook Library is another platform from where textbooks can be funded, published and licensed freely. Users can download these books for no cost and print books at lowcost. These books have been reviewed by faculty of various institutes, colleges and universities. All these books are adapted by higher education institutions, or by the institutes which are affiliated to society and professional organizations [4].

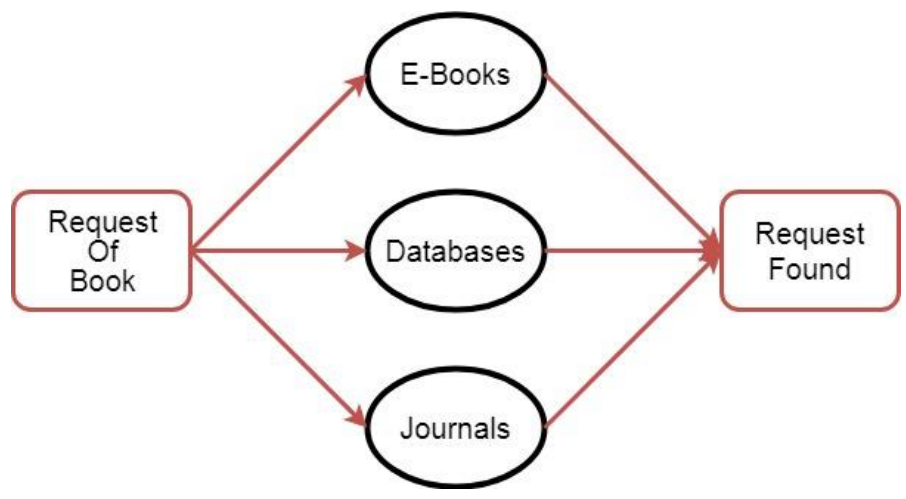

Figure 1 Model of Proposed System

OAPEN is an online library, provides fully access to academic books, specially related to domain of humanities and social sciences. This platform works with publishers to provide quality textbooks and academic books with no cost, and provides services for publishers, libraries and researchers in domain of quality assurance, deposit and digital preservation [1].

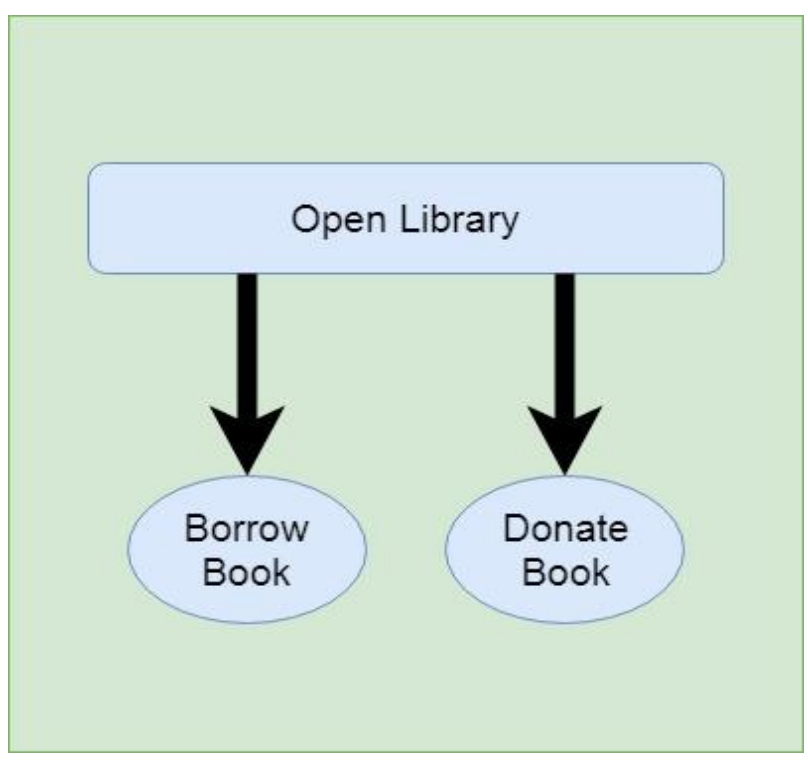

Figure 2 Open Library

Open Library is a website, where users can borrow books by logging into the network. Books of fiction, romance, action, horror, non-fiction, biographies, science, textbooks, are available on one platform. One special feature of this site is that users can make an account and being a member of this Open Library can easily borrow books of their interests. At the top-right bar of this website an option of DONATE is 
given, where users can donate their extra books, or the books which are not in their use now. These books can be textbooks, academic books or reference books, which can help others to solve their academic queries and users can benefit themselves for their exams. The site has an option of MY BOOKS on navigation bar, where users can read their downloaded collection of books whenever they are willing to do so. Total three menu items are on nav bar which has further subdomains of subjects and login options [2].

\section{PROPOSED SYSTEM}

Library Network is an online book service provider, a webbased application, consisting of 4-5 nav bar options in menu bar, such as home, the menu, book borrow, contact us. This network starts working by a request, made by it user, user log in to the network, generates request for the book, the request goes to central library/main library, search of book is made in main library, two cases can occur here.

1 st case, when book is found in central library, here the search will be stopped and user's demand will be fulfilled at level-1, by issuing book to him/her.

2nd case, when book is not available within central library boundary, the actual working starts in this scenario. A request is generated by central library to its associated libraries within the region. All libraries are connected via this network to central library, categorized as 2 nd -level libraries. The book demanded by a user, is searched in these libraries. At this point, there could be two types of situations that can occur

- If the request is found, user will receive a confirmation email and search of book will be stopped at level-2 and book will be issued to user.

- If request is not available in 2nd -level libraries, it is further forwarded to 3rd-level libraries of this network, 3rd- level libraries are not directly connected to central library, they are associated to only 2nd- level libraries. Search of book is made in this level, book is found then "book successfully found" e-mail is sent to user.

This paper not only focuses on providing give and take services of books easily but will also resolve some other major issues. One of these problems is facing difficulty in studying from PDF format books. Books in PDF format are ELearning elements but students who have medical issues like eyesight problem; feel uncomfortable studying from PDF books. They rather prefer books in hard copy, as they find it more convenient way of studying. Another issue is that most of the students can't afford expensive books, these books are required for only a semester duration, every semester has 6-7 courses and purchasing those 7 books for students is not pocket-friendly and is inconvenient, so they prefer borrowing books for some specific time period rather than buying books for such a short time period. The network will resolve these all issues.

Library Network; a web-based platform, will provide a variety of books under one platform. This app will benefit the students and also help out the librarians in reducing their workload. They will only have to write the name of the book and all related information of that book including author's name, publication year and subject will be displayed. This app will save the time of searching the book for librarians, time of going to library for students. Cost of books will be saved, student don't need to purchase them for short period of time.

\section{SUGGESTED SCHEME FOR SHARING BOOKS}

Borrowing books have some terms and conditions. Firstly it is up-to clients or students' whether they want book in soft-copy or hard-copy. If they require soft-copy of a particular book it will be mailed. If in case the client's requirement is for hardcopy, a policy of the library network is applicable here, the shipping cost is included, book will be shipped within 2-3 working days. For both cases of soft and hard copies, returning policies may vary. 15-days return policy is applicable in case of hard-copy, excluding shipping time. Returning shipping cost is also required to be paid by beneficiary/user of book. Returned book must be in the same condition, as it was at the time of delivery, any damage to book will create penalty to the user and borrowing book for him will create issue in future.

Book found from 3rd-level libraries or from any level of libraries, are delivered from shortest path, as to minimize the shipping cost. Selection of path is made by applying Salesman Travelling Algorithm, one of the classic problems in computer science. This algorithm works on optimization, provides path that is cheaper, faster and shortest. Starting point and ending points are same.

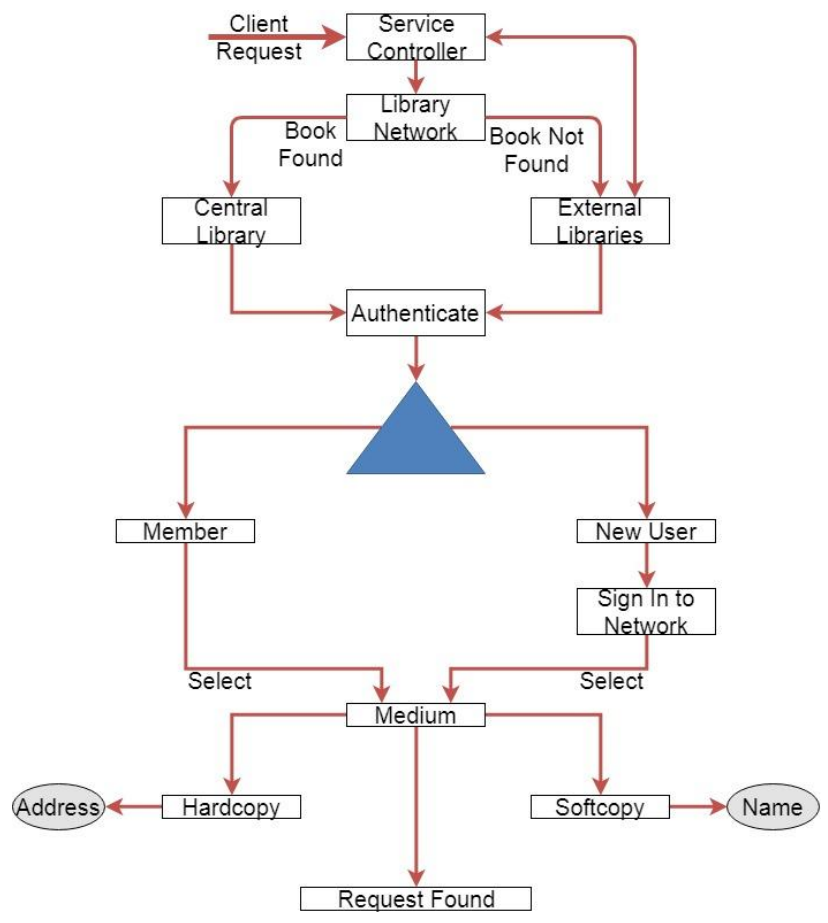

Figure 3 Suggested Scheme for Sharing Books

The regional library can't generate request to the library cells of different areas, first the request will go to city library and if book is not available the request will be forwarded to area and if request is not found it will be forwarded to various cells of the area. Level to level communication will be made this network library work properly. Salesmen Traversing Algorithm will be used to find optimal solution of delivery book from level 3 to level 1 or vice versa.

\section{SYSTEM ARCHITECTURE}

For a web application the system architecture design would include components such as, database, application server, web server, internet, browser etc. Not all of these must be included in the diagram, but the basic architecture of network is illustrated in the following diagram. 
Here system architecture of Library Book Share Network (LBSN), has controller which will work like a server, and will connect the users to the external libraries. The LBSN application works, as soon as the request is generated for a book at application layer, the request is then forwarded to data layer where the availability of book is checked in database of the LBSN. The found request is forwarded back to application layer and with the help of presentation layer (HTML and $\mathrm{CSS}$ ) representation the request is shown to user.

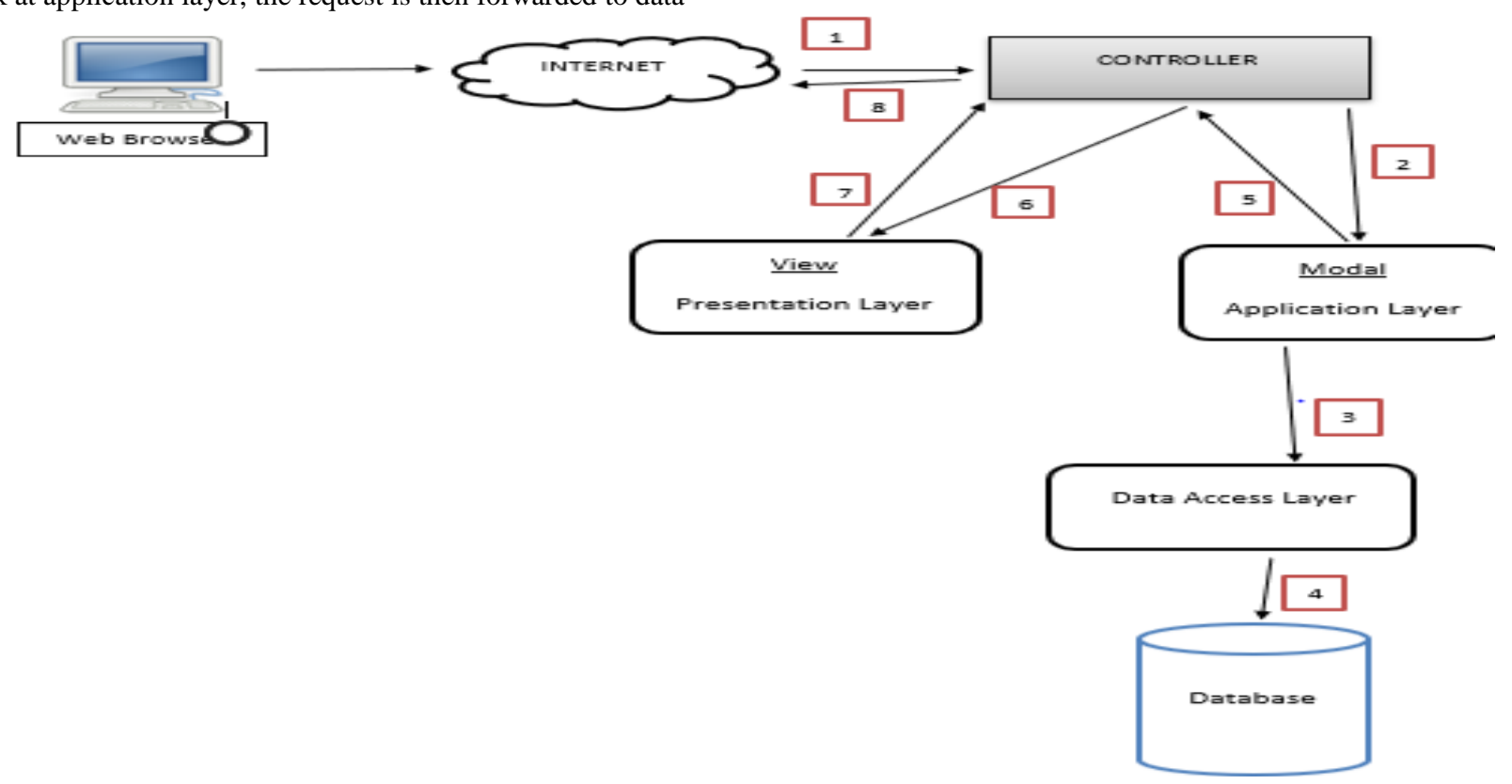

Figure 4 System Architecture

\section{REFERENCES}

[1] (UVA), U. O. (2008). Open Access Publishing in European Networks. Retrieved from OAPEN: http://www.oapen.org/content/organisation

[2] Archive, I. (n.d.). Open Library(Home). Retrieved from Open Library: https://openlibrary.org/
[3] HEC. (2004). HEC National Digital Library Program. Retrieved from HEC Digital Library: http://www.digitallibrary.edu.pk/

[4] Minnesota, C. o. (n.d.). Open Textbook Library. Retrieved from https://open.umn.edu/opentextbooks/ 